Bakhshaliyev Nijad, Ozdemir Ramazan

Bezmialem Vakif University, Istanbul, Turkey

\title{
THE IMPACT OF ATRIAL FLOW REGULATOR IMPLANTATION ON HEMODYNAMIC PARAMETERS IN PATIENTS WITH HEART FAILURE
}

\author{
Background \\ Left atrial decompression has emerged a new option to treat patients with heart failure and dyspnea \\ at rest or during exercise. Here we report the impact of atrial flow regulator (AFR) implantation on \\ hemodynamic parameters in patients at our center with heart failure and with reduced ( $\mathrm{HFrEF})$ or \\ with preserved left ventricular ejection fraction ( $\mathrm{HFpEF})$. \\ Material and methods The PRELIEVE trial is designed to assess the safety and efficacy of the AFR in patients with HFrEF or \\ HFpEF. Patients with left ventricular end-diastolic pressure $\geq 15 \mathrm{mmHg}$ at rest or $\geq 25 \mathrm{mmHg}$ during \\ exercise and with an ejection fraction $\geq 15 \%$ were enrolled. Echocardiographic data, 6-min walking \\ distance, Kansas City Cardiomyopathy Questionnaire, and brain natriuretic peptide levels were \\ assessed pre- and post-AFR implantation and at 3 mos. Invasive hemodynamic assessments were also \\ performed pre- and post-AFR implantation and at 3 mos. \\ Results $27(69.2 \%)$ patients with HFrEF and $12(30.8 \%)$ patients with HFpEF at our center were enrolled in \\ this study. A significant decrease was observed in pulmonary arterial wedge pressure regardless of EF \\ $(\mathrm{p}=0.007$ for $\mathrm{HFrEF}$ and $\mathrm{p}=0.03$ for $\mathrm{HFpEF})$. No significant difference of mean pulmonary arterial \\ pressure, right arterial pressure and cardiac output $(\mathrm{CO})$ existed at 3 months compared with pre- \\ implantation baseline values. \\ Conclusion AFR implantation led to decrease in left ventricle filling pressure without the deleterious impact on CO \\ and right heart function regardless of ejection fraction. \\ Keywords \\ For citations \\ Atrial flow regulator; diuretics; device; dyspnea; edema; heart failure; interatrial shunt; quality of life \\ Bakhshaliyev Nijad, Ozdemir Ramazan. The impact of atrial flow regulator implantation on \\ hemodynamic parameters in patients with heart failure. Kardiologiia. 2021;61(10):71-80. [Russian: \\ Бахшалиев НиАжаА, Оздемир Рамазан. Влияние имплантации устройства Аля регумяции преА- \\ серАного кровотока на параметры гемодинамики у пациентов с сердечной недостаточностью. \\ КарАиология. 2021;61(10):71-80] \\ Corresponding author_Bakhshaliyev Nijad. E-mail: bnijad@bezmialem.edu.tr
}

\section{Introduction}

Increased left atrial pressure (LAP) secondary to elevated left ventricular end-diastolic pressure (LVEDP) leads to pulmonary congestion that is responsible for dyspnea at rest or during exercise in patients with heart failure and with reduced (HFrEF) or preserved left ventricular ejection fraction (HFpEF) [1]. Decreased left ventricular ejection fraction (LVEF) in HFrEF and impaired myocardial relaxation in HFpEF cause elevated LVEDP and LAP [2, 3]. Diuretics and vasodilators are used to reduce LVEDP and LAP [4], but as heart failure progresses, the effects of medical therapy abate. The prevalence of HF is $1-2 \%$ in the general population and reaches $>10 \%$ in persons aged 70 and older [5]. Given the high prevalence of HF in the older population, drug-resistant scenarios are inevitable.

Recently, several novel device implants to treat heart failure symptoms using left atrial decompression have been tested successfully. They include the Ventura device (V-Wave Ltd., Or Akiva, Israel), the IASD (Corvia Inc., Tewksbury, MA, USA), the AFR (Occlutech, Schaffhausen, Switzerland), and the Transcatheter Atrial Shunt System (a left atrium-to-coronary sinus shunt device by Edwards
Lifesciences, Irvine, California). The latter device is placed by atriotomy, whereas the other three devices are deployed in the interatrial septum. The IASD has been investigated in HFpEF patients [6,7], and the Ventura device was tested in patients with HFrEF [8]. Both devices were proven to be safe and showed initial beneficial hemodynamic and clinical outcomes. Last year, 3-mos results of the PRELIEVE trial in both HFrEF and HFpEF patients were published in Eurointervention [9]. All three interatrial shunting devices are approved (CE-marked) for use in patients with HF.

These devices create passive left atrial decompression. In a computer simulation study, an 8-mm interatrial shunt, which was identical to the bAFR device shunt, shifted the left atrial pressure-volume loop leftward and downward [10]. This caused a minimal decrease in left ventricle output while mildly increasing right ventricle output. These results were coupled with a marked reduction in pulmonary artery wedge pressure (PAWP) $(\sim 3 \mathrm{mmHg}$ at rest and $\sim 11 \mathrm{mmHg}$ at peak exercise). Right atrial and pulmonary artery pressures did not significantly increase. The effects of interatrial shunt on pulmonary hemodynamics have been investigated in a preclinical study [11]. That study 
demonstrated the favorable effects of creating an interatrial shunt on pulmonary hemodynamics in rats with HFpEF.

Here we report the hemodynamic changes following AFR implantation at 3 mos in patients with HFrEF and HFpEF.

\section{Material and methods}

PRELIEVE is a non-randomized, prospective, multicenter, open label pilot study of the AFR. PRELIEVE has been approved by local and national ethics committees, and 19 clinical centers in Turkey, Belgium and Germany are part of the study. Prior to patient recruitement study protocol was approved by sponsor and local ethic committee in Bezmialem Vakif University (Date:29/03/2017, No: 71306642-050.01.04).

Quality of life (QoL, assessed by the Kansas City Cardiomyopathy Questionnaire (KCQQ)), New York Heart Association (NYHA) class, 6-min walking distance (6MWD), and transthoracic echocardiography (TTE) parameters are assessed during follow-up according to the protocol (Figure 1).

HFrEF and HFpEF patients were enrolled in the study. Patients with left ventricular ejection fraction (LVEF) equal to or greater than $15 \%$ and less than $40 \%$, and with documented elevated left ventricular filling pressure (PAWP $\geq 15 \mathrm{mmHg}$ at rest or $\geq 25 \mathrm{mmHg}$ during exercise) were included in the HFrEF group. Patients with LVEF equal to or greater than $40 \%$ and with documented elevated left ventricular filling pressure were included in the HFpEF group. Inclusion and exclusion criteria are summarized in Table 1.

The study follow-up period was planned to be completed in $12 \mathrm{~m}$ and consisted of eight clinical visits, i.e., screening, implantation, and six follow-up visits. 6MWD performance and QoL (KCCQ) were assessed after 1, 3, 6, and 12 mos. Transesophageal echocardiography (TEE) and right heart catheterization were performed at the 3-mon follow up visit. The study is ongoing. We reported here 3-month data.

The primary safety endpoint was the presence of serious adverse device effects (SADEs) at 3 mos, SADEs were defined as device dislocation or embolization, device-related injury of mitral or tricuspid valve, device-related intractable

Figure 1. Brief review of the study protocol

$\begin{array}{lr}\text { Physical examination } & (\text { Day } 7,30,90,180,360) \\ \text { Vital signs } & (\text { Day } 1,7,30,90,180,360) \\ \text { Laboratory testing, included BNP } & (\text { Day } 7,30,90,180,360) \\ \text { Electrocardiography } & (\text { Day } 7 \text { and 90) } \\ \text { 6-minutes walking test } & (\text { Day 30, 90, 180, 360) } \\ \text { Transthoracic echocardiography } & (\text { Day } 1,7,30,180,360) \\ \text { Transesophageal echocardiography } & (\text { Day 90) } \\ \text { KCCQ } & (\text { Day 30, 90, 180,360) } \\ \text { Right and Left Heart Catheterization } & (\text { Day 90) }\end{array}$

Table 1. Inclusion and exclusion criteria

\begin{tabular}{l|l}
\multicolumn{2}{l}{ Inclusion criteria (All criteria had to be fulfilled) } \\
\hline 1 & Age $\geq 18$ yrs \\
\hline 2 & NYHA class III/IV \\
\hline 3 & Under medical treatment (according to ESC guidelines) at least 6 mos \\
\hline 4 & History of hospitalization due to symptomatic heart failure in the last 12 mos \\
\hline 5 & $\begin{array}{l}\text { Non-significant (moderate-to-severe) } \\
\text { valvular heart diseases (aortic stenosis, mitral regurgitation and stenosis) }\end{array}$ \\
\hline 6 & Controlled arrhythmia with heart rate $\leq 110$ bpm \\
\hline 7 & Life expectancy $\geq 1$ yr \\
\hline 8 & Undergone successful balloon atrial septostomy and patient in stable condition \\
\hline 9 & $\begin{array}{l}\text { Left ventricular ejection fraction } \geq 15 \% \text { and } \leq 70 \% \\
- \text { for } \mathrm{LVEF} \geq 40 \%: \mathrm{NT} \text {-pro-BNP } \geq 125 \mathrm{pg} / \mathrm{ml}\end{array}$ \\
\hline 10 & $\begin{array}{l}\text { Elevated left ventricular filling pressures; } \\
- \text { PCWP/LVEDP } \geq 15 \text { mmHg and greater than CVP, at rest or } \\
- \text { PCWP } \geq 25 \text { mmHg, CVP }<20 \text { mmHg during exercise }\end{array}$ \\
\hline 11 & $\begin{array}{l}\text { Transseptal catheterization and transfemoral } \\
\text { vein procedure determined to be accessible }\end{array}$ \\
\hline
\end{tabular}

\section{Exclusion criteria}

\begin{tabular}{|c|c|}
\hline 1 & Sepsis or any acute infections \\
\hline 2 & History of allergic reaction to titanium/nickel, anticoagulation or antiaggregant \\
\hline 3 & Contrast media intolerance \\
\hline 4 & Pregnancy and lactation \\
\hline 5 & Occluded inferior vein cava \\
\hline 6 & History of ASD and/or ASD repair or closure device in place \\
\hline 7 & Intracardiac thrombus \\
\hline 8 & Unstable and intractable angina pectoris \\
\hline 9 & $\begin{array}{l}\text { Right ventricular dysfunction, described as following: } \\
\text { - TAPSE }<14 \mathrm{~mm} \\
\text { - RV volume } \geq \mathrm{LV} \text { volume } \\
\text { - PASP }>70 \mathrm{mmHg}\end{array}$ \\
\hline 10 & Severe valve disease or mechanical valve prosthesis \\
\hline 11 & Congenital heart defect, large PFO with significant atrial septal aneurysm \\
\hline 12 & Mitral valve stenosis \\
\hline 13 & Resting heart rate $>110 \mathrm{bpm}$ \\
\hline 14 & Clinically relevant thrombocytopenia, thrombocytosis, leucopenia, anemia \\
\hline 15 & Unable to perform $6 \mathrm{MWD}$ test \\
\hline 16 & Active malignancy \\
\hline 17 & Symptomatic carotid artery disease \\
\hline 18 & Uncontrolled systolic blood pressure $>170 \mathrm{mmHg}$ \\
\hline 19 & Severe lung disease \\
\hline 20 & History of TIA or stroke within 6 mos \\
\hline 21 & Candidates to heart transplantation \\
\hline 22 & Bleeding disorders $(\mathrm{INR}>2.0$, thrombocytes $<100000$, hemoglobin $<8.0 \mathrm{~g} / \mathrm{dl})$ \\
\hline 23 & $\begin{array}{l}\text { History of MI or PCI or CABG in last } 3 \text { mos or indication for coronary } \\
\text { intervention }\end{array}$ \\
\hline 24 & CRT implantation within last 6 mos \\
\hline 25 & Septic aneurysm \\
\hline 26 & Atrial septal thickness $>10 \mathrm{~mm}$ \\
\hline 27 & HF due to hypertrophic or infiltrative cardiomyopathy \\
\hline 28 & Thromboembolic events within last 6 mos \\
\hline 29 & Dialysis or renal insufficiency requiring dialysis \\
\hline \multicolumn{2}{|r|}{$\begin{array}{l}\text { 6MWD, 6-min walking distance; ASD, atrial septal defect; CABG, coronary artery } \\
\text { bypass grafting; CRT, cardiac resynchronization therapy; CVP, central venous pressure; } \\
\text { HF, heart failure; LVEDP, left ventricular end-diastolic pressure; MI, myocardial } \\
\text { infarction; PASP, pulmonary arterial systolic pressure; PCI, percutaneous coronary } \\
\text { intervention; PCWP, pulmonary capillary wedge pressure; PFO, patent foramen ovale; } \\
\text { RV, right ventricular; TAPSE, tricuspid annular plane systolic excursion. }\end{array}$} \\
\hline
\end{tabular}


Figure 2. AFR device ex vivo in face (a) and side view (b)

a

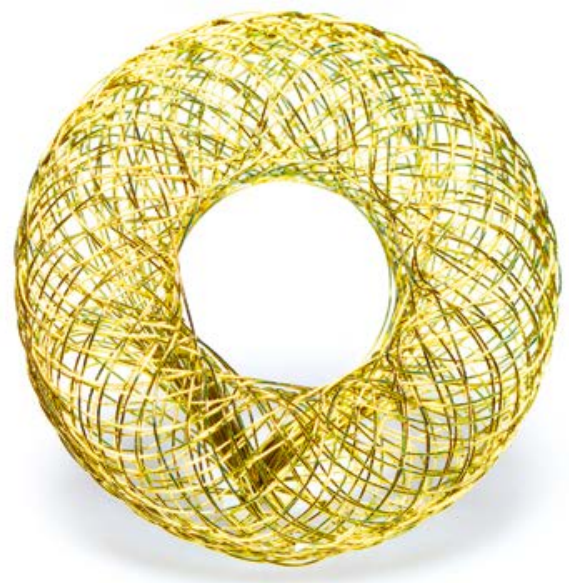

b

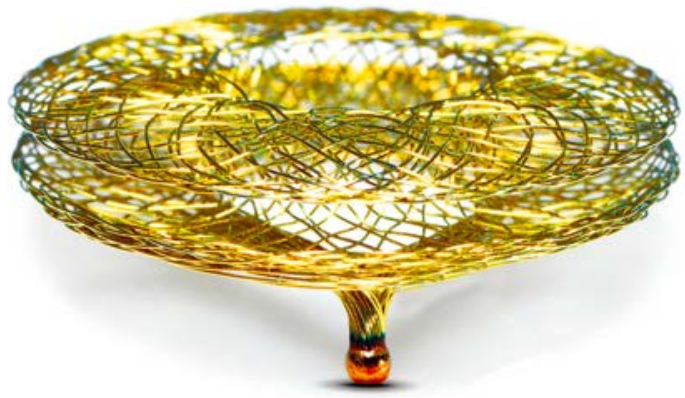

arrhythmia, or any circumstance that required device removal. The secondary safety endpoints were the rate of all serious device events (SAE) and the presence of SADEs during 12 mos after implantation.

\section{AFR device description}

The AFR device is a self-expanding, double-disc, circular device made of nitinol wire mesh with «superelastic properties» (Figure 2). A waist with a central shunt connects the discs. A welded ball structure located on the proximal disc surface serves as an adapter for the pusher cable during implantation. The AFR is available with different waist-shunt diameters, waist heights and disc diameters to provide shunts of different diameters and to accommodate varying atrial septal anatomy. Depending on the size of the AFR, the manufacturer recommends using the Occlutech Delivery System (ODS) with sizes ranging from $8 \mathrm{~F}$ to $14 \mathrm{~F}$.

\section{Procedural details}

The procedure began with local anesthesia and sedation. Right and left cardiac catheterizations were performed. PAWP, pulmonary artery and right heart chamber pressures, central venous, and aortic and left ventricular pressures were recorded. Blood samples for gas analysis were obtained. Cardiac output (CO), pulmonary and systemic vascular resistance were calculated. Hemodynamic findings were

Figure 3. Fluoroscopic view of the implantation procedure (a-c). Color Doppler view of implanted AFR device on TEE (d)
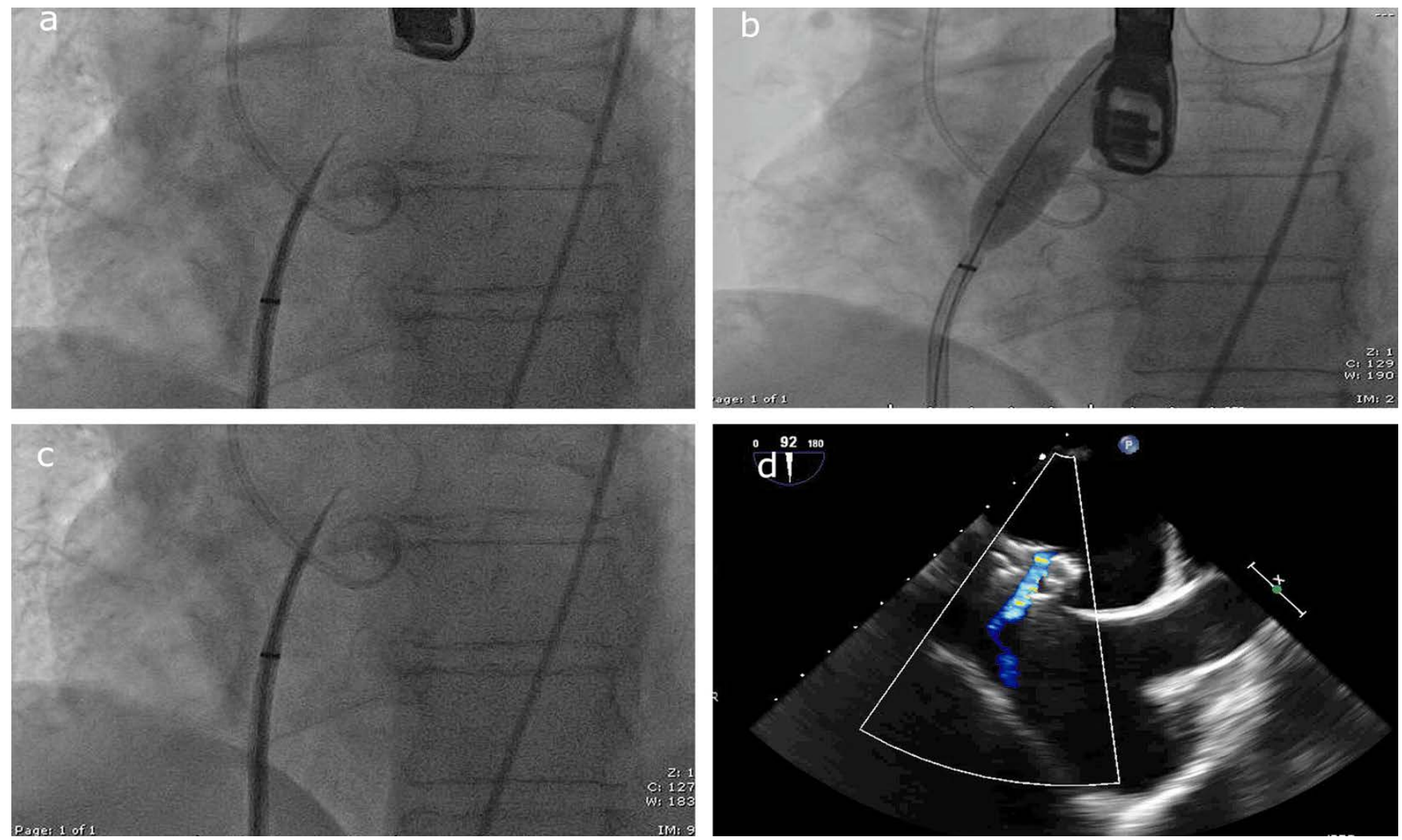
Table 2. Baseline characteristics of study population

\begin{tabular}{|c|c|c|}
\hline Variable & $\begin{array}{c}\text { HFrEF } \\
\text { patients, } n=27\end{array}$ & $\begin{array}{c}\text { HFpEF } \\
\text { patients, } n=12\end{array}$ \\
\hline \multicolumn{3}{|c|}{ Demographic features } \\
\hline Age, yrs & $68.3 \pm 7.1$ & $70.6 \pm 7.2$ \\
\hline Gender, males & $18(66.7)$ & $7(58.3)$ \\
\hline $\mathrm{BMI}, \mathrm{kg} / \mathrm{m}^{2}, \mathrm{IQR}$ & $26.61(23.30-28.98)$ & $29.07(26.17-32.38)$ \\
\hline \multicolumn{3}{|c|}{ Medical History } \\
\hline Hypertension & $18(67)$ & $9(75)$ \\
\hline Dyslipidemia & $8(30)$ & $2(17)$ \\
\hline Diabetes mellitus & $10(37)$ & $7(58)$ \\
\hline CAD & $13(48)$ & $7(58)$ \\
\hline CABG & $1(4)$ & $2(17)$ \\
\hline $\mathrm{AF}$ & $11(41)$ & $4(33)$ \\
\hline COPD & $2(7)$ & $0(0)$ \\
\hline Stroke & $0(0)$ & $0(0)$ \\
\hline Thyroid disease & $4(15)$ & $3(25)$ \\
\hline \multicolumn{3}{|c|}{ Medications } \\
\hline Beta-blockers & $24(89)$ & $12(100)$ \\
\hline MRA & $19(70)$ & $4(33)$ \\
\hline ACEI/ARB & $15(56)$ & $10(83)$ \\
\hline ARNI & $1(4)$ & $0(0)$ \\
\hline Ivabradine & $3(11)$ & $0(0)$ \\
\hline Digoxin & $7(26)$ & $2(17)$ \\
\hline Statin & $7(26)$ & $4(33)$ \\
\hline Oral nitrate & $6(22)$ & $4(33)$ \\
\hline Warfarin & $2(7)$ & $0(0)$ \\
\hline DOAC & $7(26)$ & $7(58)$ \\
\hline Amiodarone & $8(30)$ & $4(33)$ \\
\hline SSRI & $5(19)$ & $2(17)$ \\
\hline
\end{tabular}

Data are mean $\pm \mathrm{SD}$, median with $25^{\text {th }}-75^{\text {th }}$ interquartile range, or $\mathrm{n}(\%)$. ACEI, angiotensin convertase enzyme inhibitory; AF- atrial fibrillation; ARB; angiotensin receptor blocker; ARNI-angiotensin receptor neprilysin inhibition; BMI;body mass index; $C A B G$; coronary artery bypass grafting; $C A D$ - coronary artery disease; COPD; chronic obstructive pulmonary disease; DOAC; direct oral anticoagulation; MRA; mineralocorticoid receptor antagonist; SSRI- selective serotonin receptor inhibition.

used to confirm subjects' study eligibility. Device sizing was performed according to hemodynamic and clinical data as well as atrial septal thickness (Figure 3). Transseptal puncture was performed with TEE guidance and under general anesthesia. After the transseptal puncture, unfractionated heparin was given intravenously to achieve an activated clotting time (ACT) $>250 \mathrm{sec}$, and a stiff wire was placed in the left upper pulmonary vein. The puncture site in the septum was predilated by balloon inflation to a diameter $2 \mathrm{~mm}$ larger than the intended shunt, i.e., the AFR device diameter. After the AFR device was loaded onto the pusher, the AFR was advanced through the delivery sheath into the left atrium. Following appropriate positioning of the left atrial disc, the right atrial disc was deployed. Before
Table 3. Baseline clinical, laboratory and echocardiographic characteristics

\begin{tabular}{|c|c|c|}
\hline Variable & $\begin{array}{c}\text { HFrEF } \\
\text { patients, } n=27\end{array}$ & $\begin{array}{c}\text { HFpEF } \\
\text { patients, } n=12\end{array}$ \\
\hline \multicolumn{3}{|c|}{ Clinical features } \\
\hline NYHA III, n (\%) & $25(93)$ & $11(92)$ \\
\hline NYHA IV, n (\%) & $2(7)$ & $1(8)$ \\
\hline 6MWTD, m & $165(982-31)$ & $175(105-280)$ \\
\hline KCCQ-OS & $59.53(51.72-72.60)$ & $54.96(38.35-74.69)$ \\
\hline $\mathrm{SBP}, \mathrm{mmHg}$ & $119(106-130)$ & $131(112-154)$ \\
\hline $\mathrm{DBP}, \mathrm{mmHg}$ & $72(60-82)$ & $70(62-76)$ \\
\hline \multicolumn{3}{|c|}{ Echocardiographic findings } \\
\hline LVEF & $27.0(21.0-31.3)$ & $48.6(40.5-55.8)$ \\
\hline LVED diameter, mm & $62.23(53.93-70.25)$ & $56.61(51.50-61.00)$ \\
\hline LVES diameter, mm & $51.83(43.53-57.88)$ & $40.19(33.72-48.30)$ \\
\hline $\begin{array}{l}\text { Left atrial } \\
\text { diameter, mm }\end{array}$ & $41.0(36.8-44.0)$ & $42.0(40.0-45.0)$ \\
\hline $\begin{array}{l}\text { Mitral valve E/E' } \\
\text { ratio }\end{array}$ & $9.61(5.98-11.84)$ & $13.44(8.81-17.44)$ \\
\hline TAPSE, $\mathrm{cm}$ & $2.24(1.60-2.77)$ & $2.17(1.83-2.44)$ \\
\hline \multicolumn{3}{|c|}{ Laboratory findings } \\
\hline Hemoglobin, g/dl & $13.45(11.32-15.20)$ & $12.61(11.62-13.59)$ \\
\hline $\begin{array}{l}\text { Serum } \\
\text { creatinine, } \mathrm{mg} / \mathrm{dl}\end{array}$ & $1.15(092-1.45)$ & $0.97(0.82-1.08)$ \\
\hline $\mathrm{eGFR}, \mathrm{ml} / \mathrm{min}$ & $65.24(43.50-81.37)$ & $72.25(64.00-82.74)$ \\
\hline BUN, mg/dl & $26.01(19.40-30.89)$ & $21.28(14.49-26.64)$ \\
\hline $\begin{array}{l}\text { Bilirubin, } \\
\text { total, mg/dl }\end{array}$ & $0.57(0.26-0.95)$ & $0.39(0.22-0.67)$ \\
\hline $\mathrm{BNP}, \mathrm{pg} / \mathrm{mL}$ & $921(147.85-1329.30)$ & $334(117.10-239.4)$ \\
\hline
\end{tabular}

Data are median with $25^{\text {th }}-75^{\text {th }}$ interquartile range or $n(\%) .6 \mathrm{MWTD}$, 6 min walking test distance; BNP, brain natriuretic peptide; DBP, diastolic blood pressure; BUN, blood urine nitrogen; eGFR, estimated glomerular filtration rate; KCCQ-OS, Kansas City Cardiomyopathy Questionnaire Overall Score; LVEF, left ventricular ejection fraction; LVED, left ventricular end-diastolic; LVES, left ventricular end-systolic; NYHA, New York Heart Association; SBP, systolic blood pressure; TAPSE, tricuspid annular plane systolic excursion.

releasing the device from its pusher, the Minnesota maneuver [10] was used to test device stability, and TEE was performed to confirm correct device position and patency. Following device placement, right and left heart catheterizations were repeated.

During the first 3 mos after implantation, patients received oral clopidogrel $75 \mathrm{mg}$ and acetylsalicylic acid $100 \mathrm{mg}$ OD. Thereafter, acetylsalicylic acid $100 \mathrm{mg}$ OD was recommended for patients not on anticoagulation. If a patient needed anticoagulation for any reason, daily clopidogrel $75 \mathrm{mg}$ was added. Standard endocarditis prophylaxis was administered during the procedure and for a minimum of 6 mos following implantation. 
Table 4. Procedural characteristics

\begin{tabular}{|c|c|c|}
\hline Variable & HFrEF patients & HFpEF patients \\
\hline \multicolumn{3}{|c|}{ Implantation success, $n(\%)$} \\
\hline \multicolumn{3}{|l|}{ Device fenestration diameter } \\
\hline $8 \mathrm{~mm}$ & $22(82)$ & $11(92)$ \\
\hline $10 \mathrm{~mm}$ & $5(19)$ & $1(8)$ \\
\hline \multicolumn{3}{|l|}{ Device waist height } \\
\hline $5 \mathrm{~mm}$ & $27(100)$ & $10(83)$ \\
\hline $10 \mathrm{~mm}$ & $0(0)$ & $2(17)$ \\
\hline \multicolumn{3}{|c|}{ Procedural duration } \\
\hline $\begin{array}{l}\text { Balloon atrial septostomy } \\
\text { duration, min }\end{array}$ & $10(4-14)$ & $9(4-14)$ \\
\hline $\begin{array}{l}\text { Device implantation } \\
\text { duration, min }\end{array}$ & $4(3-5)$ & $4(3-6)$ \\
\hline $\begin{array}{l}\text { Overall catheterization } \\
\text { duration, min }\end{array}$ & $86(70-103)$ & $89(71-105)$ \\
\hline Fluoroscopy time, $\min$ & $23(18-27)$ & $21(16-27)$ \\
\hline $\begin{array}{l}\text { Qp/Qs ratio immediately } \\
\text { after implantation of AFR }\end{array}$ & $1.23 \pm 0.29, \mathrm{n}=22$ & $1.18 \pm 0.37, \mathrm{n}=10$ \\
\hline $\mathrm{Qp} / \mathrm{Qs}$ ratio at $3 \mathrm{mos}$ & $1.32 \pm 0.39, \mathrm{n}=22$ & $1.12 \pm 0.32, \mathrm{n}=10$ \\
\hline $\begin{array}{l}\text { Left-to-right } \\
\text { shunt flow at } 3 \text { mos }\end{array}$ & $22(100)$ & $10(100)$ \\
\hline Periprocedural TEE & $25(100)$ & $12(100)$ \\
\hline
\end{tabular}

Data are mean $\pm S D$, median with $25^{\text {th }}-75^{\text {th }}$ interquartile range, or $\mathrm{n}(\%)$. AFR, atrial flow regulator; TEE, transesophageal echocardiog raphy.

Figure 4. Flowchart of study population

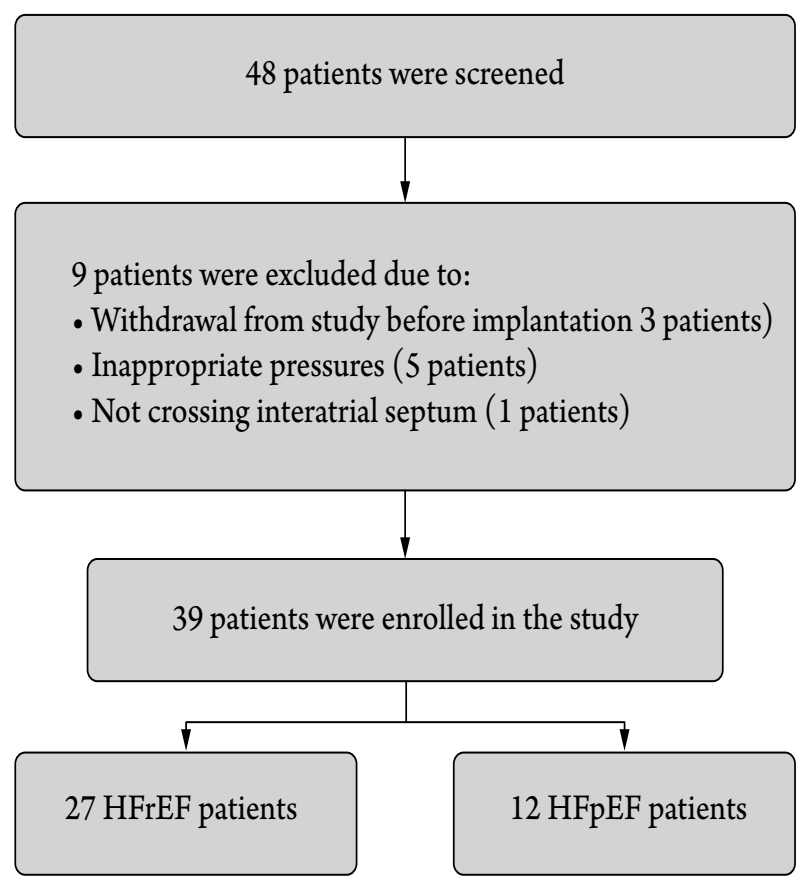

\section{Statistical methods}

Normally distributed continuous variables are reported as mean \pm standard deviation, skewed continuous variables are presented as median with interquartile ranges $\left(25^{\text {th }}-75^{\text {th }}\right)$, and categorical variables are expressed as percentiles. Paired $t$-tests were used for group comparisons if the paired means distribute normally, otherwise the Wilcoxon Signed Rank test was used. All statistical analyses were 2-tailed and $\mathrm{p}<0.05$ was considered statistically significant. All statistical analyses were performed with SPSS version 22 .

\section{Results \\ Study Populations and Baseline Characteristics}

A flowchart showing patient enrollment is shown in Figure 4. A total of 48 patients were screened and 39 patients were enrolled in the study at our center. Twenty-seven (69.2\%) patients were in the HFrEF group and $12(30.8 \%)$ patients were in the HFpEF group. Eighteen (66.7\%) HFrEF patients and 7 (58.3\%) HFpEF patients were male. The median age of the HFrEF population was $68.3 \pm 7.1 \mathrm{yrs}$ and $70.6 \pm 7.2$ yrs in the HFpEF population. Additional study population information and characteristics are listed in Table 2.

\section{Procedural results}

Procedural data are summarized in Table 3. Overall catheterization times were similar in both groups (HFrEF: 86 (70-103) min and HFpEF: 89 (71-105) min. The AFR device with an inner fenestration diameter of $8 \mathrm{~mm}$ (HFrEF: $81 \%$ and HFpEF: $92 \%$ ) and a height of $5 \mathrm{~mm}$ (HFrEF: $100 \%$ and HFpEF: $83 \%$ ) was used in most of the study population (Table 4). The final opening size was assessed by intraprocedural TEE in terms of device recoiling. We did not observe any recoiling of the devices. Left-to-right shunting through the device was documented immediately after deployment in all patients, and device patency was $100 \%$ at the 3-mo follow up, as assessed by TEE or TTE.

\section{Safety events at the 3-mo follow up examination}

Safety data are summarized in Table 5. Adverse device effects were seen in two HFrEF patients (injection site reaction and paresthesia) and all had resolved. No adverse device events and deaths were seen in the HFpEF patients. One HFrEF patient died within 1 wk after device implantation due to pneumonia and septicemia. SAEs were observed in 12 (44.4\%) HFrEF and 4 (33.3\%) HFpEF patients. Worsening heart failure was observed in $3(11.1 \%)$ patients, all in the HFrEF group. Iliac vein thrombosis occurred in one HFrEF patient. Acute arterial deoxygenation was not reported, and all patients were discharged after implantation. Procedure related serious adverse effects (SAEs) were observed in 2 patients (5.1\%), all in the HFrEF group. No strokes/transient ischemic attacks (TIA), myocardial infarctions, or complications requiring device removal were seen in either group. Device patency was maintained in all patients at the 3-mo follow-up examination. 
Table 5. Adverse events during 3-month follow-up

\begin{tabular}{|c|c|c|c|}
\hline Event & $\begin{array}{c}\text { HFrEF } \\
\text { patients, } \\
\mathbf{n}=\mathbf{2 7}\end{array}$ & $\begin{array}{c}\text { HFpEF } \\
\text { patients, } \\
n=12\end{array}$ & $\begin{array}{c}\text { All patients, } \\
\mathbf{n}=39\end{array}$ \\
\hline $\begin{array}{l}\text { Hospitalization for } \\
\text { worsening HF }\end{array}$ & $3(11.1)$ & $0(0)$ & $3(7.7)$ \\
\hline Death & $1(3.7)$ & 0 & $1(2.6)$ \\
\hline Stroke or TIA & 0 & 0 & 0 \\
\hline Myocardial infarction & 0 & 0 & 0 \\
\hline Device removal & 0 & 0 & 0 \\
\hline Procedure-related SAE & 2 & 0 & 2 \\
\hline SADE & 0 & 0 & 0 \\
\hline $\begin{array}{l}\text { SAE rate, total } \\
\text { numbers of events }\end{array}$ & 30 & 10 & 1 \\
\hline Patients with SAE & $12(44.4)$ & $4(33.3)$ & $16(41.0)$ \\
\hline $\begin{array}{l}\text { AE rates, total } \\
\text { number of events, }\end{array}$ & 23 & 43 & 66 \\
\hline Patients with $\mathrm{AE}$ & $4(14.8)$ & $11(91.7)$ & $15(38.5)$ \\
\hline $\mathrm{ADE}$ total number & 2 & 0 & 2 \\
\hline Patients with ADE & $2(7.4)$ & 0 & $2(5.1)$ \\
\hline
\end{tabular}

Data are $\mathrm{n}(\%)$. ADE, adverse device event (s); AE, adverse event (s); HF, heart failure; SADE, serious adverse device event (s); SAE, serious adverse event (s); TIA, transient ischemic attack.

\section{Impact on hemodynamic parameters. HFrEF population}

Detailed hemodynamic variables are summarized in Table 6. Compared with pre-implantation, PAWP and LVEDP were significantly reduced at $3 \operatorname{mos}(\mathrm{p}=0.007$ and $\mathrm{p}=0.01$, respectively). There was no difference between pre-implantation and 3-mos cardiac output $(\mathrm{p}=0.45)$. No significant difference existed between post-implantation $\mathrm{Qp} / \mathrm{Qs}$ and $\mathrm{Qp} / \mathrm{Qs}$ calculated at $3 \mathrm{mos}(1.23 \pm 0.29$ vs. $1.32 \pm 0.39$, respectively). Mean pulmonary pressure decreased mildly but not significantly $(p>0.99)$. There was no increased in RA pressure at 3 mos compared with baseline (median 10.00 vs. 9.33, respectively, $\mathrm{p}=0.70$ ) (Figure 5).

\section{HFpEF population}

PAWP was significantly improved at 3 mos, from median 18 to $10 \mathrm{mmHg}(\mathrm{p}=0.03)$. There was no change in cardiac output at 3 mos compared with baseline, median 4.67 vs $4.991 / \mathrm{min}$, respectively $(\mathrm{p}=0.67)$. Median mean pulmonary arterial pressure decreased from 28 to $23 \mathrm{mmHg}$, but it was not statistically significant $(\mathrm{p}=0.39)$. No significant difference was observed between pre-implantation and 3-month mean right arterial pressure $(\mathrm{p}=0.80)$ (Figure 6).

\section{Discussion}

We assessed the impact of AFR device implantation on hemodynamic parameters in both HFrEF and HFpEF patients. Device implantation were performed without any complications in either group. No events requiring device removal occurred after implantation. At 3 mos, device patency was present in all assessed cases. A left-to right shunt was seen immediately after device placement and at 3 mos. No acute or chronic arterial deoxygenation was observed after AFR device deployment nor during the 3-mo follow up period.

Two different situations show that left atrial decompression may be effective in heart failure. The first is Lutembacher's syndrome, which is defined as the concomitant rheumatic mitral stenosis and atrial septal defect [11]. This combination is associated with a relatively small increase in left atrial pressure during rest and effort, and a delay in the onset of dyspnea compared to isolated mitral

Table 6. Invasive measurements

\begin{tabular}{|c|c|c|c|c|c|c|}
\hline Variable & $\begin{array}{c}\text { HFrEF } \\
\text { patients, } \\
\text { baseline, } n=24\end{array}$ & $\begin{array}{c}\text { HFrEF } \\
\text { patients, } \\
\text { at } 3 \text { mos, } n=24\end{array}$ & $\begin{array}{l}\mathrm{p}, \\
\text { value }\end{array}$ & $\begin{array}{c}\text { HFpEF } \\
\text { patients, } \\
\text { baseline, } n=10\end{array}$ & $\begin{array}{c}\text { HFpEF } \\
\text { patients, } \\
\text { at } 3 \text { mos, } \\
n=10\end{array}$ & $\mathbf{p}$ \\
\hline RAP, mmHg & $9.33(5.25-12.75)$ & $10.00(4.50-12.75)$ & 0.70 & $10.90(7.25-14.25)$ & $10.80(3.25-19.50)$ & 0.80 \\
\hline $\mathrm{PAP}, \mathrm{mmHg}$ & $29(18-33)$ & $24(16-29)$ & 1.00 & $28(20-36)$ & $23(11-33)$ & 0.39 \\
\hline $\mathrm{CO}, 1 / \mathrm{min}$ & $4.45(3.48-4.79)$ & $4.91(3.80-5.05)$ & 0.45 & $4.67(3.86-5.44)$ & $4.99(4.01-5.55)$ & 0.65 \\
\hline PCWP, mmHg & $19(16-24)$ & $14(8-18)$ & 0.007 & $18(17-21)$ & $10(4-17)$ & 0.037 \\
\hline LVEDP, mmHg & $18(14-22)$ & $14(8-18)$ & 0.01 & $16(14-21)$ & $11(4-17)$ & 0.10 \\
\hline Systolic aortic pressure, $\mathrm{mmHg}$ & $136(124-151)$ & $140(119-155)$ & 0.88 & $154(135-173)$ & $152(132-173)$ & 0.88 \\
\hline
\end{tabular}

Data are median with $25^{\text {th }}-75^{\text {th }}$ interquartile range, CO, cardiac output; LVEDP, left ventricular end-diastolic pressure; PAP, pulmonary artery pressure; PCWP, pulmonary capillary wedge pressure; RAP, right atrial pressure. 


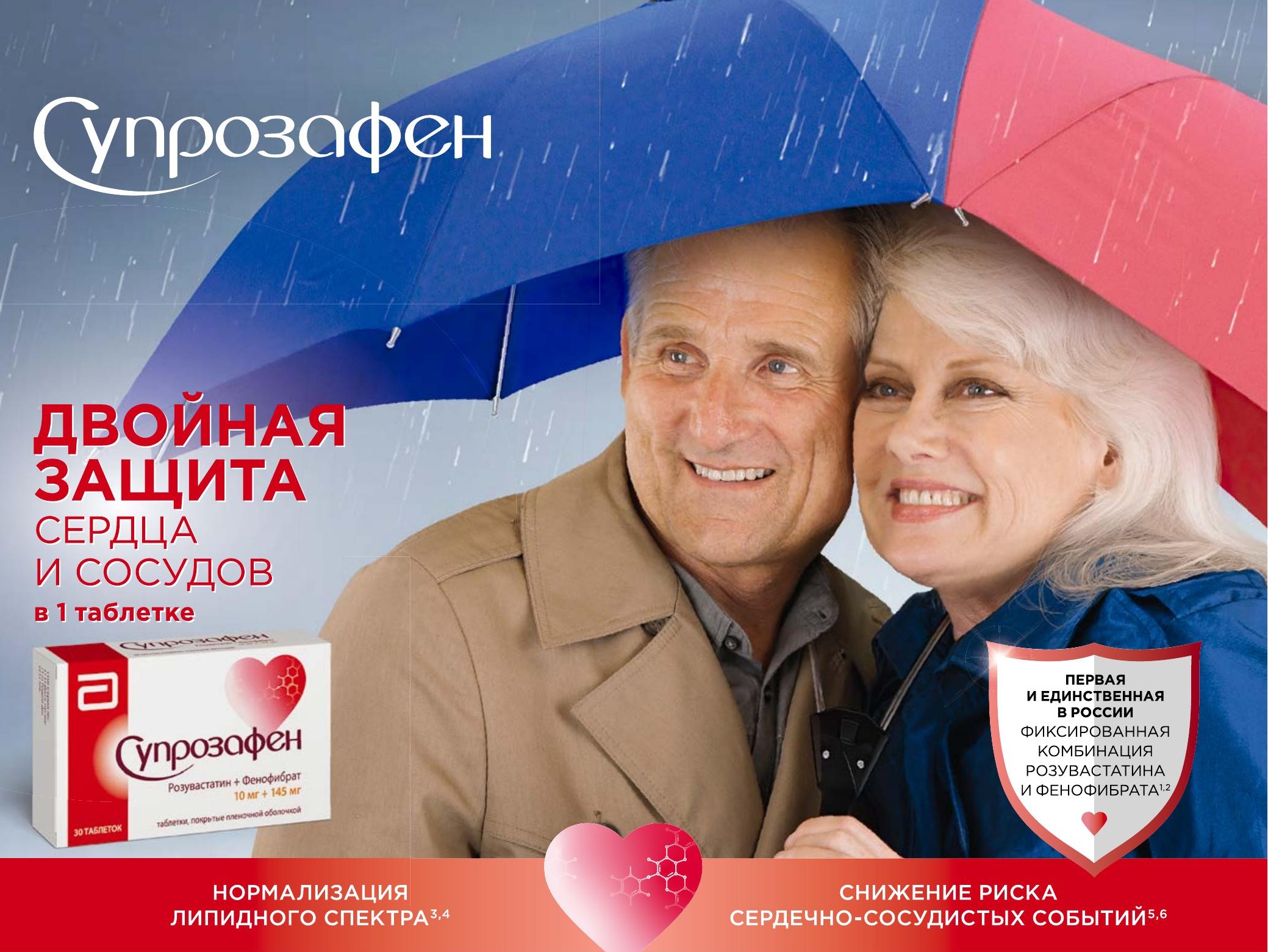

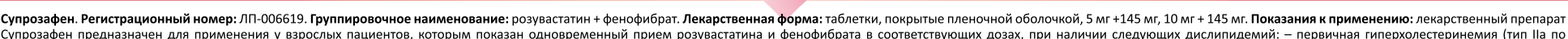

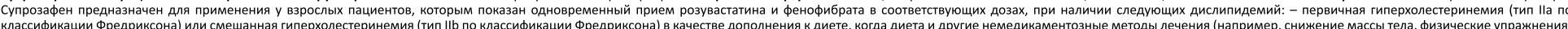

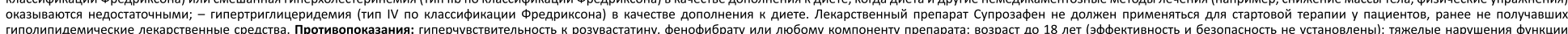

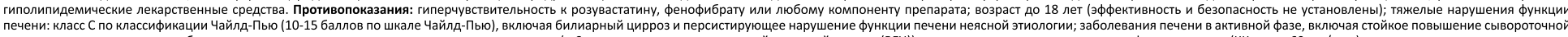

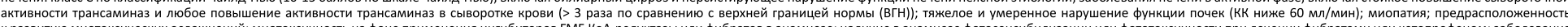

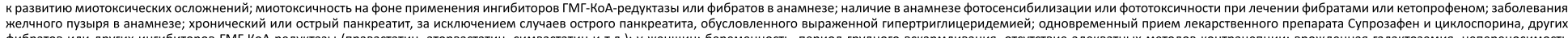

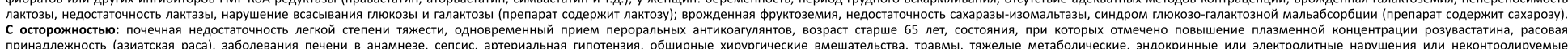

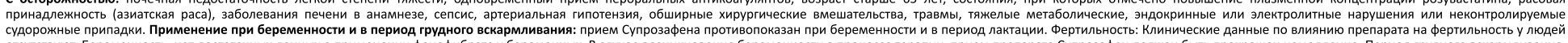

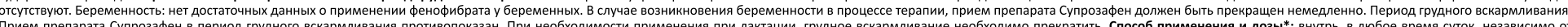

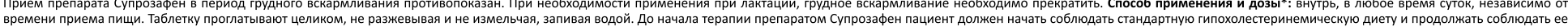

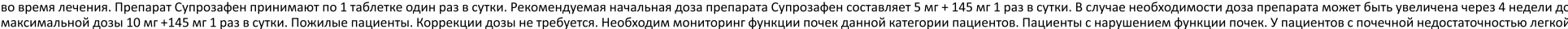

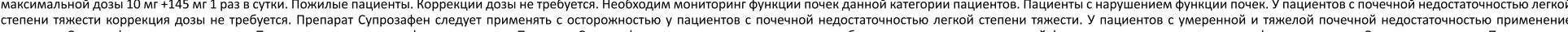

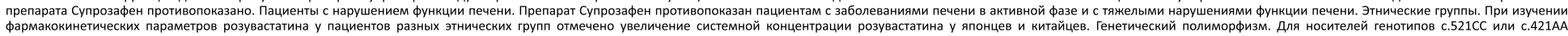

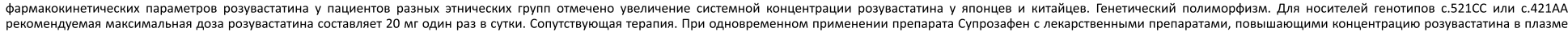

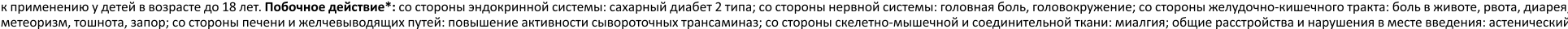

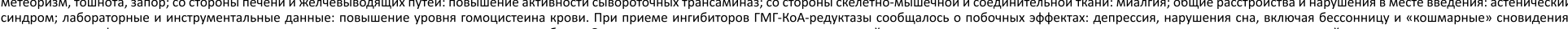

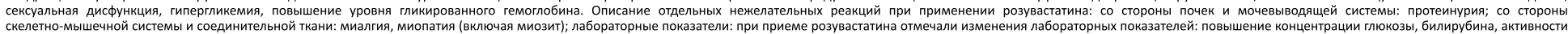

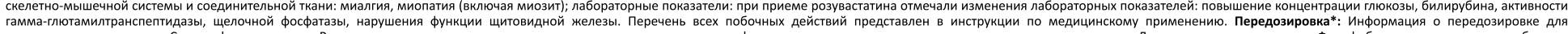

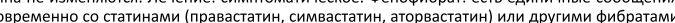

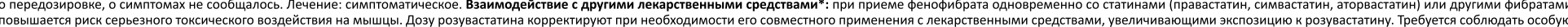

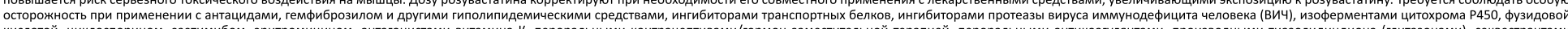

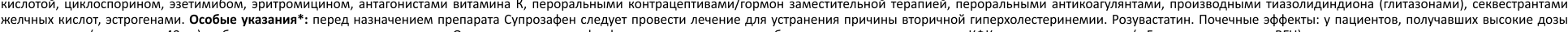

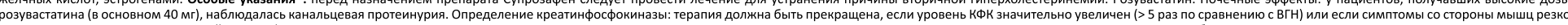

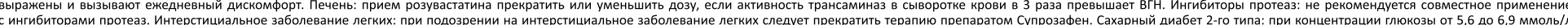

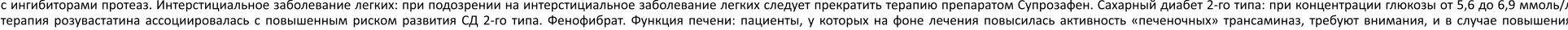

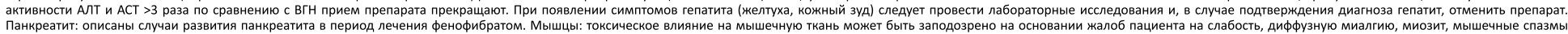

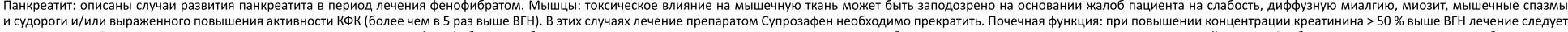
приостановить. Гематогические нарушения: после начала терапии фенофибратом наблюдалось легкое или умеренное снижение уровня гемоглобина, снижение гематокрита и уменьшение числа лейкоцитов СоОбцалесь о

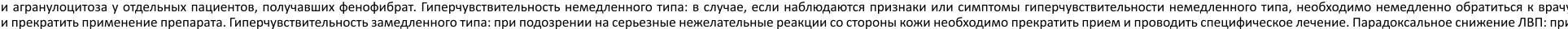

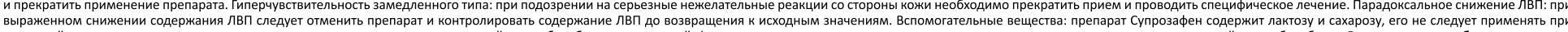

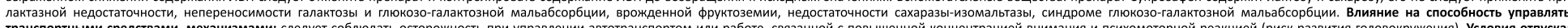

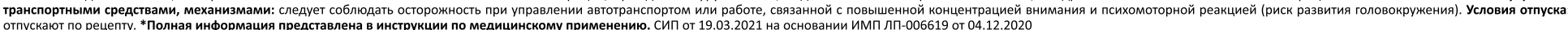

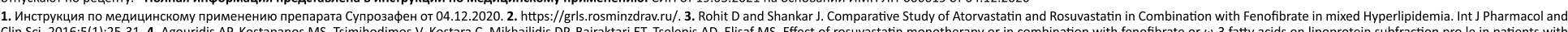

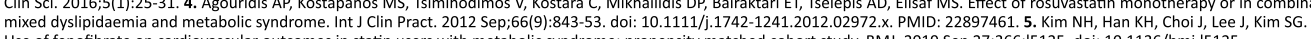
Use of fenofibrate on cardiovascular outcomes in statin users with metabolic syndrome: propensity matched cohort study. BMJ. 2019 Sep 27;366:I5125. doi: 10.1136/bmj.l15125. ООО «Эбботт Лэбораториз» 
stenosis. The same volume of blood may lead to lower pressure in the right atrium compared to the left atrium due to greater right atrial distensibility [12]. This theory was supported by Little's anatomical study in isolated canine hearts [13]. Similar results were reported in post-MitraClip (Abbott, Chicago, USA) cases performed by the transseptal route. Recent publications demonstrated that hemodynamic and clinical results may be effective in selected MitraClip cases with persistent iatrogenic septal defects. In a study by Ikenaga et al., although left atrial pressure was higher in postMitraClip patients with persistent iatrogenic atrial septal defect (iASD) compared to those without iASD, the lack of difference between NYHA FC and brain natriuretic peptide (BNP) values indicated that left atrial decompression may be beneficial [14]. In the MITHRAS study, percutaneous closure of the iASD following transcatheter mitral valve repair was compared with conservative treatment. Patients with Qp/Qs >1.3 were included in the study. At 5-mo follow-up, there were no differences in terms of 6MWDT, NHYA class and peripheral edema between groups [15]. The second situation is the effect of atrial septal defect (ASD) closure on left ventricular and atrial hemodynamics in adults [16], where it was shown that ASD closure triggers left heart failure in patients with high left ventricular enddiastolic pressures. In light of the data obtained from these two contrasting situations but with similar results, it can be postulated that interatrial shunt devices may be effective in treating isolated left heart failure [17].

The main concerns regarding left atrial decompression with interatrial shunt devices are:

1) successful implantation and stability of the device;

2) long-term shunt patency;

3) the risk of paradoxical embolism;

4) right heart volume overload and increased pulmonary pressure at the long-term follow-up;

5) decrease in left ventricle output.

The shunt diameter of the Ventura V-Wave device is $5 \mathrm{~mm}$. The first generation version of this device contained a bioprosthetic valve, and stenosis or occlusion of the shunt was seen in $50 \%$ of subjects at 1-yr follow up [18]. After examination of an explanted heart, it was found that the occlusion/stenosis was associated with the bioprosthetic valve rather than due to thrombus. V-Wave designed a second generation device without a bioprosthetic valve. Shunt patency was maintained with this device for up to $1 \mathrm{yr}$ [19].

The InterAtrial Shunt Device (IASD) has a shunt diameter of $8 \mathrm{~mm}$. This device has been studied in HFpEF patients [20]. Shah et al. could not find any evidence of shunt stenosis/shunt occlusion at $12 \operatorname{mos}$ [21].

To date, no cases of paradoxical embolism have been reported in post-MitraClip patients despite having relatively
Figure 5. Temporal changes in PAP (a), mean RAP (b), $\mathrm{CO}$ (c) and mean PAWP (d) in HFrEF patients
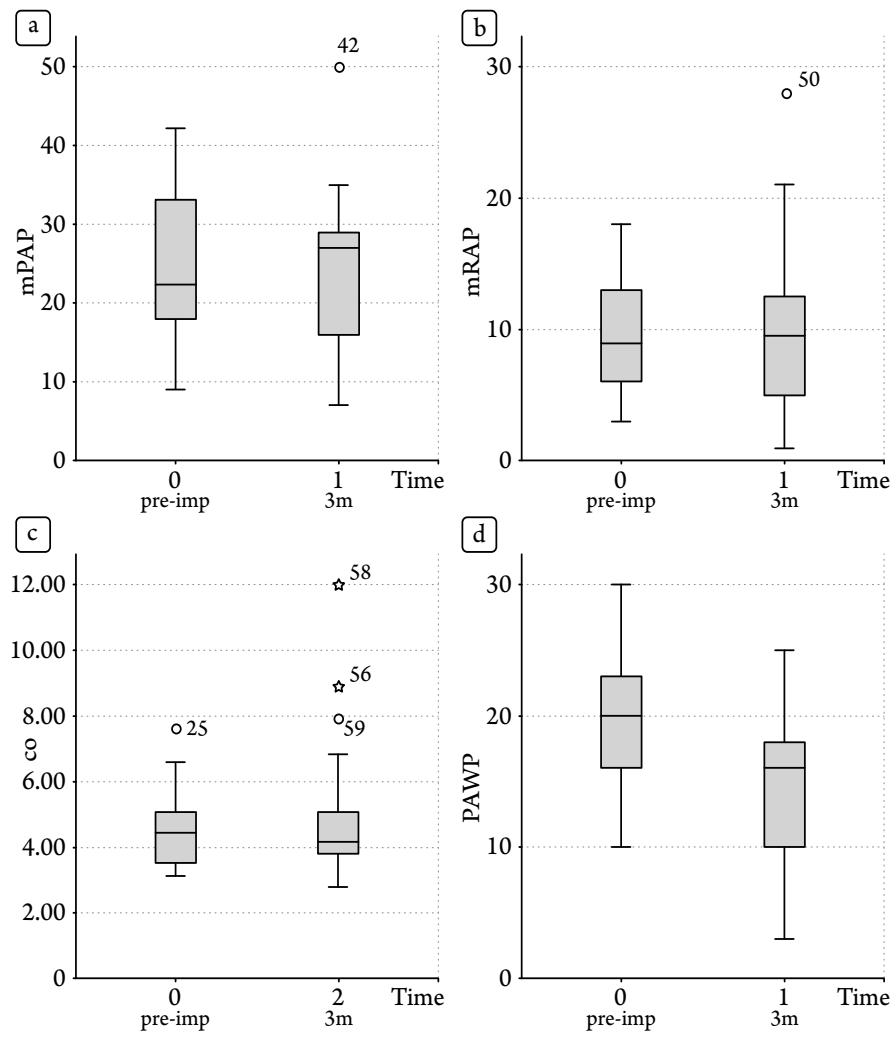

Figure 6. Temporal changes in CO (a), mean PAP (b), PAWP (c) and mean RAP (d) in HFpEF patients
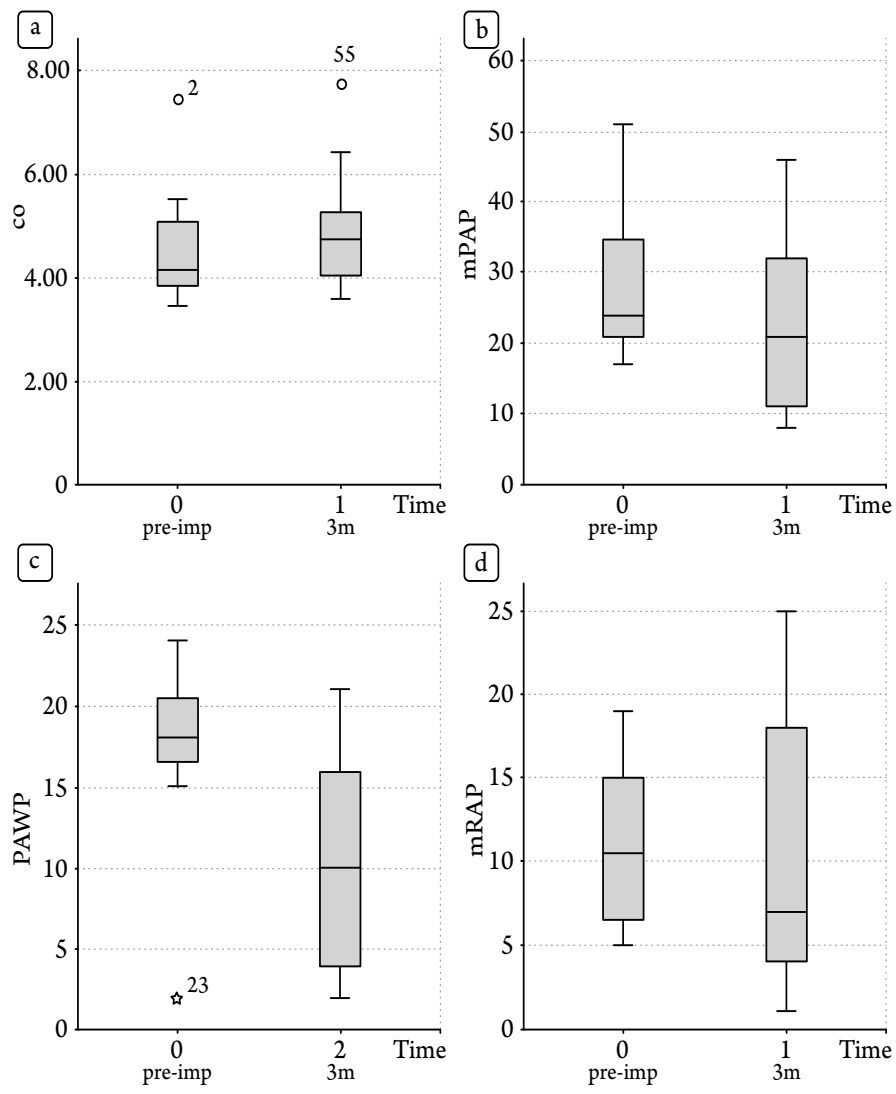
larger iASD [22]. In studies of two different interatrial shunt devices, Del Trigo et al. [8] and Feldman et al. [23] reported no events associated with paradoxical embolism or device thrombus.

An increase in pulmonary artery pressure as a result of volume overload created by the left-right shunt is another concern. However, as known from congenital heart disease patients, small defects, e.g., an ASD of $10 \mathrm{~mm}$, are not associated with deleterious hemodynamic effects during a long-term follow-up period [24]. These data were confirmed in a simulation study by Kaye et al. [25]. They observed that the interatrial shunt with a diameter of 8-9 $\mathrm{mm}$ provided a significant decrease in PAWP without serious volume loading in the right ventricle or a serious decrease in left ventricular output [25]. The lumen diameters of the AFR device are 8 and $10 \mathrm{~mm}$. In the present study, 33 (85\%) patients were implanted with an AFR device with a diameter of $8 \mathrm{~mm}$. An AFR with a diameter of $10 \mathrm{~mm}$ was implanted in patients whose resting left ventricular end-diastolic pressure was less than $15 \mathrm{mmHg}$ but with exercise LVEDP equal to or greater than $25 \mathrm{mmHg}$. The $\mathrm{Qp} / \mathrm{Qs}$ ratio was $1.32 \pm 0.39$ in the HFrEF group and $1.12 \pm 0.32$ in the HFpEF group at the end of 3 mos. There was no significant decrease in resting cardiac output in either group at the end of 3 mos (HFrEF: $4.45(3.48-4.79)$ vs $4.91(3.80-5.05) \mathrm{p}=0.45$; HFpEF: 4.67
(3.86-5.44) vs $4.99(4.01-5.55), \mathrm{p}=0.65)$. Compared to the basal value, a significant decrease was observed in PAWP at the end of 3 mos in both groups (HFrEF: 19 (16-24) $\mathrm{mmHg}$ vs 14 (8-18) $\mathrm{mmHg}, \mathrm{p}=0.007$; HFpEF: 18 (17-21) $\mathrm{mmHg}$ vs. $10(4-17) \mathrm{mmHg}, \mathrm{p}=0.037)$.

\section{Study limitations}

This study has several limitations. First, this was an open label, non-randomized trial. The results are limited by being conducted at one center and with a small sample size. Second, the follow-up period was restricted to 3 mos after the procedure. The PRELIEVE study is ongoing, and further results will be available in the future. Third, the study was a single-arm trial, and we could not compare these results with placebo therapy.

\section{Conclusion}

Regardless of left ventricular ejection fraction, AFR implantation decreased left ventricle filling pressure without a deleterious impact on cardiac output or on right heart function.

\section{No conflict of interest is reported.}

The article was received on $14 / 03 / 2021$

\section{REFERENCES}

1. Gheorghiade M, Filippatos G, De Luca L, Burnett J. Congestion in Acute Heart Failure Syndromes: An Essential Target of Evaluation and Treatment. The American Journal of Medicine. 2006;119(12):S3-10. DOI: 10.1016/j.amjmed.2006.09.011

2. Borlaug BA, Nishimura RA, Sorajja P, Lam CSP, Redfield MM. Exercise Hemodynamics Enhance Diagnosis of Early Heart Failure With Preserved Ejection Fraction. Circulation: Heart Failure. 2010;3(5):588-95. DOI: 10.1161/CIRCHEARTFAILURE.109.930701

3. Maeder MT, Thompson BR, Brunner-La Rocca H-P, Kaye DM. Hemodynamic Basis of Exercise Limitation in Patients With Heart Failure and Normal Ejection Fraction. Journal of the American College of Cardiology. 2010;56(11):855-63. DOI: 10.1016/j. jacc.2010.04.040

4. Ponikowski P, Voors AA, Anker SD, Bueno H, Cleland JGF, Coats AJS et al. 2016 ESC Guidelines for the diagnosis and treatment of acute and chronic heart failure: The Task Force for the diagnosis and treatment of acute and chronic heart failure of the European Society of Cardiology (ESC) Developed with the special contribution of the Heart Failure Association (HFA) of the ESC. European Journal of Heart Failure. 2016;18(8):891-975. DOI: 10.1002/ejhf.592

5. Bui AL, Horwich TB, Fonarow GC. Epidemiology and risk profile of heart failure. Nature Reviews Cardiology. 2011;8(1):30-41. DOI: 10.1038/nrcardio.2010.165

6. Søndergaard L, Reddy V, Kaye D, Malek F, Walton A, Mates M et al. Transcatheter treatment of heart failure with preserved or mildly reduced ejection fraction using a novel interatrial implant to lower left atrial pressure. European Journal of Heart Failure. 2014;16(7):796801. DOI: $10.1002 /$ ejhf.111

7. Malek F, Neuzil P, Gustafsson F, Kaye DM, Walton A, Mates M et al. Clinical outcome of transcatheter treatment of heart failure with preserved or mildly reduced ejection fraction using a novel implant. Inter- national Journal of Cardiology. 2015;187:227-8. DOI: 10.1016/j.ijcard.2015.03.198

8. Del Trigo M, Bergeron S, Bernier M, Amat-Santos IJ, Puri R, Campelo-Parada $\mathrm{F}$ et al. Unidirectional left-to-right interatrial shunting for treatment of patients with heart failure with reduced ejection fraction: a safety and proof-of-principle cohort study. The Lancet. 2016;387(10025):1290-7. DOI: 10.1016/S0140-6736(16)00585-7

9. Paitazoglou C, Özdemir R, Pfister R, Bergmann MW, Bartunek J, Kilic $\mathrm{T}$ et al. The AFR-PRELIEVE trial: a prospective, non-randomised, pilot study to assess the Atrial Flow Regulator (AFR) in heart failure patients with either preserved or reduced ejection fraction. EuroIntervention. 2019;15(5):403-10. DOI: 10.4244/EIJ-D-19-00342

10. Erdem A, Saritas T, Zeybek C, Yucel IK, Erol N, Demır H et al. Transthoracic echocardiographic guidance during transcatheter closure of atrial septal defects in children and adults. The International Journal of Cardiovascular Imaging. 2013;29(1):53-61. DOI: 10.1007/ s10554-011-9933-z

11. Sambhi MP, Zimmerman HA. Pathologic physiology of Lutembacher syndrome. The American Journal of Cardiology. 1958;2(6):681-6. DOI: 10.1016/0002-9149(58)90264-9

12. Hochrein M, Eckardt W. Zur Dynamik Verschiedener Klappenfehler, Insbesondere der Mitralstenose und Aorteninsuffizienz. Klinische Wochenschrift. 1930;9(1):12-4. DOI: 10.1007/BF01740703

13. Little RC. Volume elastic properties of the right and left atrium. The American Journal of Physiology. 1949;158(2):237-40. DOI: 10.1152/ajplegacy.1949.158.2.237

14. Ikenaga H, Hayashi A, Nagaura T, Yamaguchi S, Yoshida J, Rader $\mathrm{F}$ et al. Left atrial pressure is associated with iatrogenic atrial septal defect after mitral valve clip. Heart. 2019;105(11):864-72. DOI: 10.1136/heartjnl-2018-313839

15. Lurz P, Unterhuber M, Rommel K-P, Kresoja K-P, Kister T, Besler C et al. Closure of Iatrogenic Atrial Septal Defect After Transcatheter Mi- 
tral Valve Repair: The Randomized MITHRAS Trial. Circulation. 2021;143(3):292-4. DOI: 10.1161/CIRCULATIONAHA.120.051989

16. Chigurupati K, Reshmi LJ, Gadhinglajkar S, Venkateshwaran S, Sreedhar R. Pulmonary edema following transcatheter closure of atrial septal defect. Annals of Cardiac Anaesthesia. 2015; 18(3):441-4. DOI: 10.4103/0971-9784.159827

17. De Rosa R, Schranz D. Creation of a restrictive atrial left-to-right shunt: a novel treatment for heart failure. Heart Failure Reviews. 2018;23(6):841-7. DOI: 10.1007/s10741-018-9741-9

18. Rodés-Cabau J, Bernier M, Amat-Santos IJ, Ben Gal T, Nombela-Franco L, García Del Blanco B et al. Interatrial Shunting for Heart Failure: Early and Late Results from the First-inHuman Experience With the V-Wave System. JACC. Cardiovascular interventions. 2018;11(22):2300-10. DOI: 10.1016/j. jcin.2018.07.001

19. Guimaraes L, Bergeron S, Bernier M, Rodriguez-Gabella T, del Val D, Pibarot $\mathrm{P}$ et al. Initial Experience with the Second-Generation V-Wave Shunt for Treating Patients with Chronic Heart Failure. EuroIntervention. 2020;15:1426-8. DOI: 10.4244/EIJ-D-19-00291

20. Hasenfuß G, Hayward C, Burkhoff D, Silvestry FE, McKenzie $S$, Gustafsson F et al. A transcatheter intracardiac shunt device for heart failure with preserved ejection fraction (REDUCE LAP-HF): a multicentre, open-label, single-arm, phase 1 trial. The Lancet. 2016;387(10025):1298-304. DOI: 10.1016/S01406736(16)00704-2
21. Shah SJ, Feldman T, Ricciardi MJ, Kahwash R, Lilly S, Litwin S et al. One-Year Safety and Clinical Outcomes of a Transcatheter Interatrial Shunt Device for the Treatment of Heart Failure with Preserved Ejection Fraction in the Reduce Elevated Left Atrial Pressure in Patients With Heart Failure (REDUCE LAP-HF I) Trial: A Randomized Clinical Trial. JAMA Cardiology. 2018;3(10):968-77. DOI: 10.1001/ jamacardio.2018.2936

22. Kadado AJ, Islam A. Iatrogenic atrial septal defect following the MitraClip procedure: A state-of-the-art review. Catheterization and Cardiovascular Interventions. 2021;97(7):e1043-52. DOI: 10.1002/ ccd.29149

23. Feldman T, Mauri L, Kahwash R, Litwin S, Ricciardi MJ, van der Harst $\mathrm{P}$ et al. Transcatheter Interatrial Shunt Device for the Treatment of Heart Failure With Preserved Ejection Fraction (REDUCE LAP-HF I [Reduce Elevated Left Atrial Pressure in Patients With Heart Failure]): A Phase 2, Randomized, Sham-Controlled Trial. Circulation. 2018;137(4):364-75. DOI: 10.1161/CIRCULATIONAHA.117.032094

24. Baumgartner H, De Backer J, Babu-Narayan SV, Budts W, Chessa M, Diller G-P et al. 2020 ESC Guidelines for the management of adult congenital heart disease. European Heart Journal. 2021;42(6):563645. DOI: 10.1093 /eurheartj/ehaa554

25. Kaye D, Shah SJ, Borlaug BA, Gustafsson F, Komtebedde J, Kubo S et al. Effects of an interatrial shunt on rest and exercise hemodynamics: results of a computer simulation in heart failure. Journal of Cardiac Failure. 2014;20(3):212-21. DOI: 10.1016/j.cardfail.2014.01.005 